\title{
ACADEMIC YOUTH'S EDUCATION AND CAREER ABROAD: A CASE STUDY OF SUSTAINABLE EDUCATION IN THE UK
}

\author{
RASA RAČIŪNAITĖ-PAUŽUOLIENĖ \\ Department of Cultural Studies, Faculty of Humanities, \\ Vytautas Magnus University \\ V. Putvinskio str. 23-419, Kaunas LT-44243, Lithuania \\ E-mail address: rasa.raciunaite-pauzuoliene@vdu.lt \\ ORCID: https://orcid.org/0000-0001-8744-6301
}

\begin{abstract}
Aim. The research aim of this article is to explore academic youth's education process and career in the UK. The research focuses on Lithuanian students from three prestigious British universities.

Methods. The study revealed three questions: the reasons of students choises to study in prestigious higher schools of the UK, students' satisfaction in terms of their education process; their placement in the labor market, or academic/business career. To answer the research questions qualitative research was conducted by using structured, partly-structured in-depth interviews, the questionnaire forms, discussions, and observation methods.

Results. The analysis of the empirical research data revealed that the determining factor of students' choices was the high quality of the studies and international work perspectives after graduation as well as the rating of the universities and the recommendations of senior fellow students, progressive learning and living environment. Furthermore, they had the possibility to become part of the international social web. The results of the survey indicate that students give more value to individualism emphasizing achievement, critical thinking, high level of education. They also appreciate the possibilities to apply knowledge in real-world setings, also to the career in international business or academic field, which is garanteed by most reputable universities. In such evironment students are encouraged to be responsible actors and to create a more sustainable world (UNESCO (ESD), 2017).

Cognitive value. With the help of a case study of education in the UK, the paper reveals the sustainable education perspectives.
\end{abstract}

Key words: Academic's youth education, career, identity, Lithuanians, the UK 


\section{INTRODUCTION}

$\mathrm{I}_{\mathrm{tan}}^{\mathrm{n}}$ the recent years, education has become a central element of debates for sustainable development of personality. The process of education starts in early childhood from cradle to marriage and continues throughout life (Račiūnaitè, 2002). Thereby, education plays an important role in lifelong process of personal development. Education has several purposes: preparation of students for the labour market, preparation for life and personal development (Reference Framework of Competencies for Democratic Culture (RFCDC), 2018). All those purposes have gained utmost importance in current, rapidly changing society. Cultural and technological, economic and demographic changes require a person to continuously learn, reflect and act upon new challenges and possibilities in work, in private and public life (RFCDC, 2018).

The paper examines study process abroad, recruitment practices and placement of students and alumni from the prestigious universites of the UK in the labor market. It also focuses on the perception of cultural identity of new wave immigrants. One of the largest Lithuanian immigrants' communities in England was chosen as the subject of the research.

Since the enlargement of EU in 2004, over a million central eastern Europeans have found employment in Britain (Ciupijus, 2011). Emigration especially increased during the 2008-2009 global economic crisis. Experts maintain that during 22 years over 30 per cent of population left Lithuania, most of them young people and qualified specialists. The main reasons of emigration were low salary, lack of jobs, disappointing opportunities of selfrealisation and career, ineffective science and education system (Rakauskienė \& Ranceva, 2012). The aim of this research is to analyse the experiences of new wave Lithuanian immigrants, as well as their study process, academic and business career. The research focuses on the students from three prestigious British universites, who came to England after the new countries were accessed to the European Union in 2004.

The following tasks of research have been raised to specify the aim: (1) to find out the reasons of students to chose study in prestigious higher schools of England; (2) to examine students' satisfaction of study process; (3) to investigate the recruitment practices and placement of graduate students in the labor market, academic or business career.

The main issue of this research is to reveal the changes of identity and cultural orientations of young generation from Lithuania in the UK during the last years. To fulfil this issue, a survey including a qualitative research of thirty respondents was undertaken.

The main source of the paper derives from ethnographic material gathered in England and Lithuania in 2017 carrying out the project "Cultural and Religious Identity of Lithuanians in England" (Reg. No. SA-1) co-funded from The Council for the Protection of Ethnic Culture (Račiūnaitè-Paužuolienè, 2017, 2019). 


\section{LITERATURE REVIEW}

Migration topic is a relatively new field of studies in the Baltic States. Nevertheless, the issue of international students migration as well as their career abroad receives increasing attention in recent decade. There are some surveys related to migration of academic youth from the Baltic States abroad (Merkys, Baršauskienė, \& Antinienè, 2006; Skačkauskaitè, 2007; Aidis \& Krupickaitė, 2007, 2009; Märtsin, 2010b; Rakauskienè \& Ranceva, 2012; Kaša, 2015; Antinienė \& Lekavičienė, 2018; Račiūnaitè-Paužuolienė, 2017, 2019), external and internal migration in the context of globalization (Repečkienè, Kvedaraitè, \& Žvirelienè, 2009), the impact of the study environment on students' solutions (Ramanauskaitè, Vaišnys, Kairaitytė \& Buivydas, 2013; RamanauskaitèKiškina, Vaišnys \& Kairaitytė-Užupė, 2015), brain drain or brain waste (Didžgalvytė \& Pukelienė, 2010; Hazans, 2015), theoretical discourse of students migration (Sipavičienè, Jeršovas \& Radzevičius, 2013) and methodological challenges (Mierina \& Korolyeva, 2015a; Mierina, 2019), emigration for employment and education purposes of students (Kvedaraitè, Repečkienè, Glinskienè \& Bakšys, 2011; Kvedaraitè, Bakšys, Repečkienė, \& Glinskienė, 2015; Parutis, 2011, 2013; Mackela, 2018).

Researchers also focus on students' identities changing process abroad. For example, Estonian scholar Marian Märtsin (2010b) proposes an alternative conceptualization of identity. According to this conceptualization, identity construction involves rupturing life-experience, which makes the person aware of another perspective and the reality of being different. Märtsin's research carried out in 2010 through experiences of young Estonians, who made study-visits to the UK. The survey highlights some aspects in Estonians' self-definition in relation to Eastern-European identity in current England (Märtsin, 2010b).

Latvian scholars Inta Mierina and Ilze Korolyeva (2015b) focus on young Latvian migrants, their integration into the local communities abroad, and the extend to which they maintain close ties to their home countries. They pay special attention to emigrants' identity changes with time (Mierina \& Koroleva, 2015). Rita Kaša $(2015,2019)$ analyses how internationally mobile students from Latvia finance their higher education abroad and how it affects their return migration intentions. She makes a conclusion, that "accessibility and affordability of higher education are important factors that influence higher education destination country decisions among internationally mobile students from Latvia" (Kaša, 2015, p. 237).

The study Latvijas emigrantu kopienas: Ceribu diaspora (Mierina, 2015) is based on the largest survey of emigrants recently made in Latvia and Europe. It highlights the specific migration related problems characteristic to East-Central European countries. The study focuses on all Latvians and Latvian nationals abroad, characterises the problem of emigration in Latvia and discusses methodological solutions concerning the study of emigrants. The book is also dedicated to the analysis of employment and education of Latvian migrants abroad. 
There is a large literature on international student migration and their labor mobility in the world. Some scholars see international education as a direct manifestation of globalization (Mattheus \& Sidhu, 2005). Some of them highlight the interdependence of education, globalization and neo-liberalism (Brooks \& Waters, 2011; Mattheus \& Sidhu, 2005). Researchers who focus on young people, in postmodern society, emphasize the impact of identity formation. These scholars (Dolby \& Rizvi, 2008) maintain that a lot of young people cultivate their identities within the context of global mobility; they do not consider themselves as tourists or immigrants, but people who occupy a new cultural space. They are influenced by global culture, through the media, Internet, movies and fashion. Their identities are inextricably linked to modern trends (Dolby \& Rizvi, 2008). Scholars categorise geographical mobile youth into a few groups: (1) those who consider themselves "citizen of the world," mostly those of dual nationality; (2) those who move because of political or economical reasons; and (3) those who move for educational purposes and a new identity (Dolby \& Rizvi, 2008, p. 5). These scholars reveal the possibilities and risk of young people's transnational, commodified identities.

Some scholars emphasise the links between student migration and their participation in labor market worldwide (Brooks \& Waters, 2011; Brown \& Tannock, 2009). Higher education abroad may enable exceptional opportunities within the global labour market. For example, some authors (Brown \& Tannock, 2009) emphasise a "global war for talent" which has been taking place over the past decade between most prestigious companies worldwide, opening up a global market for skills. So internationally recognised qualifications assume an important role in such a labour market. These scholars examine the implications the global war for talent has for education policy. They argue that the global war for talent adds to the development of neoliberalism, which seeks to liberalise the global movement of high skill labour, not only that of capital and commodities (Brown \& Tannock, 2009).

Long-term career success is seen by some authors as a direct manifestation of professional skills and knowledge. This issue is analyzed by researchers' groups from the United States of America. For example, Hart Research Association surveys of Employers and College Students Conducted on Behalf of the Association of American Colleges \& Universities highlight that the majority of employers and college students recognize the importance of breadth and depth skills as well as good knowledge to achieve long-term career success (Hart Research Associates, 2015). The most highly valued skills and knowledge areas tested are two communication skills (written and oral), "teamwork skills, ethical decision-making, critical thinking, and the ability to apply knowledge in real-world settings" (Hart Research Associates, 2015, p. 1).

Satisfaction with study process, also, well-being could be considered as one of crucial elements of sustainable development of young people (Stasulane, 2017). Education for Sustainable Development (ESD) is a powerful tool which enables young people to strive for sustainable future; to transform society by developing knowledge, skills, values and behaviours necessary for sustain- 
able development. Young people, threrefore, are encouraged to be responsible actors who create a more sustainable world (UNESCO (ESD), 2017).

Some scholars emphasise the impact of ESD in the education of the 21st century. Students are to be prepared not only for employment in a sustainable economy, they must gain skills and values in order to live sustainable lifestyles on this planet. This includes personal development and responsible citizenship (Bell, 2016).

\section{METHODOLOGY AND FIELDWORK CHARACTERISTICS}

The study was organized in 2017. The field research has been conducted since $29^{\text {th }}$ April untill $30^{\text {th }}$ September 2017. The study sample consists of three communities of Lithuanian students and alumni from three prestigious universities in the UK. These universities are considered to be the top 10 universities according to the QS World University Rankings 2016-2017 (QS World University Rankings, 2016-2017) and top 5 universities in Europe according to The Times Higher Education World University Rankings 2018 (The Times Higher Education World University Rankings, 2018).

Lithuanian immigrants were qualitatively surveyed during the field research in England and Lithuania. Interviews with migrants in England were conducted face-to-face in cafes, parks, pubs or respondents' colleges, while interviews with return migrants on vacation in Lithuania were conducted in such public spaces as Kaunas (the second largest city of Lithuania) airport. The survey was based on face-to-face methodology, it also included Web-survey using different sources of recruiting respondents: social networking such as Skype, Facebook, websites of three prestigious universities in the UK, websites of different diaspora organizations and diaspora media.

It should be noted that web survey has certain advantages and disadvantages. Current scholars emphasise the main advantages of web survey: the possibility of achieving a large sample in a number of countries (Mierina, 2019), the possibility of anonymity and the respondents' ability to fill in the questionnaire at any time (Grandcolas, Rettie, \& Marusenko, 2003). The main disadvantage, however, is subjective selection of respondents and limited number of sociodemographic groups accessed via the Internet (Mierina, 2019).

The ethnographic material was gathered by the author using anthropological fieldwork methods such as structured, partly-structured in-depth interviews. Additionally a questionnaire form, discussions, observation methods, and in some cases snowballing sampling were used. During the time the research was being performed, 30 respondents from different social groups (current students and alumni, the research workers, businessmen, white-collar workers and intellectuals, managers at private sector and nonprofit organizations, including Non-governmental Organizations) were interviewed. The length of interview was from 45 minutes till 3 hours. Interviewees in England were contacted through websites of three prestigious universities in the UK, personal contacts (acquaintances); leaders of community organizations, and 
volunters. In order to maintain objectivity during fieldwork the researcher avoided interviewing close friends and relatives.

Respondents were selected on the basis of purposive selection criteria. The stratification of the sample was accomplished by country of origin (Lithuanian interviewees $(\mathrm{N}-30)$ ), gender (most equal number of male $(\mathrm{N}-16)$ and female (N-14)), age (the age range from 20 to 36), ethnicity (the majority of Lithuanians), marital status (the majority were single, some were married and had a child), education (secondary and higher), time of immigration in the UK (since 2004 and later), and academic disciplines (such as the humanities, social sciences, natural and exact sciences). The sample contained 30 respondents. Below we present a Table 1 which summarises 4 participants and their characteristics by gender, marital status, education, ethnicity and academic disciplines. The majority of respondents are Lithuanians, but some of them (5 from 30 respondents) have other nations roots: Jewish, Russian, Polish roots (1 respondent), French (1), German (1), Russian roots (1), also, Moldovan and Ukrainian roots (1 respondent). Most of them are representatives of natural and exact sciences (21 repondents) with a small percentage of those representing social and humanitarian sciences (10 respndents). The majority of respondents (27) are single and only 3 persons are married, 1 of whom has a child. It should be noted, that the research is anonymous, thus all names given to interwees are pseudonyms, also, the titles of three universities are not mentioned.

Table 1

Characteristics of 4 respondents

\begin{tabular}{|c|c|c|c|c|c|c|}
\hline No & Birth & Gender & $\begin{array}{l}\text { Marital } \\
\text { status }\end{array}$ & Education & Ethnicity & $\begin{array}{l}\text { Academic } \\
\text { discipline }\end{array}$ \\
\hline 1. & 1990 & Male & Single & $\begin{array}{l}\text { Higher } \\
\text { (Alumnus) }\end{array}$ & Lithuanian & Social Sciences \\
\hline 2. & 1990 & Male & Single & $\begin{array}{l}\text { Higher } \\
\text { (Alumnus) }\end{array}$ & Lithuanian & $\begin{array}{l}\text { Natural Sciences/ } \\
\text { Medicine }\end{array}$ \\
\hline 3. & 1991 & Male & Married & Postgraduate & Lithuanian & Social Sciences \\
\hline 4. & 1981 & Female & Married & $\begin{array}{l}\text { Higher } \\
\text { (Alumnus) }\end{array}$ & Lithuanian & Natural Sciences \\
\hline
\end{tabular}

Source: own research.

According to Nadine Dolby \& Fazal Rizvi (2008) classification, such geographical mobile academic youth's group could be assigned to those young people who move abroad for educational purposes and create new networks and identities.

\section{RESULTS AND DISSCUSION}

A modern academic society of young people is very dynamic - it exposes them to different types of orientations, thinking styles, and behaviours (Lekunze \& Strom, 2017). Those young people, who are studying abroad at 
prestigious universities, have a lot of opportunities to create new international networks, and to work together with people who try to change the world.

The examples presented in the paper focus on the academic youth's life experience, and the article shows how young people with prestigious education interpret their different experience. This survey includes four selected case studies from 30 respondents. It focuses on academic youth's motivation to move abroad to prestigious globally acknowledged universities to pursue contemporary higher education. Four in-depth interviews reflect the respondents' personal experiences of being migrants in England and their integration experience in the British society. The group investigated includes Lithuanian students from three prestigious English universities - they came to England after Lithuania became member of EU in 2004. Most of the respondents were either undergraduate or postgraduate students, some of them had already obtained a university degree and were pursuing their careers in the UK. The responses of the latter group helped to learn about academic or business career possibilities for young people in the international job market.

The majority of young people investigated had graduated from prestigious gymnasiums in the biggest Lithuanian cities, the greatest numbers comprising former students of Vilnius Lyceum, the Gymnasium of Kaunas University of Technology and Panevėžys Juozas Balčikonis Gymnasium. The respondents were born in between 1981 and 1997. Members of the group investigated distinguish themselves as exceptionally talented, highly intelligent, motivated, ambitious, having a clearly defined aim in life and striving for its realization. According to the survey, most of them were attracted by the possibility to acquire better education, to be hired by prestigious international business companies or academic institutions. Most of them are representatives of natural and exact sciences.

Four semi-structured, in-depth interviews were conducted with four Lithuanians living in England (2 persons), Germany (1 person) and in England and Lithuania in the same breadth (1 person) in order to gain information about their personal experiences abroad.

At the initial period of the research, some questions were addressed by the respondents through analysis of their experiences focusing on the reasons of migration in England and on the students' satisfaction of studies process. Later the main issue of investigation was the integration of students in the local and multicultural British environment and the extent to which they maintain their cultural identity.

Laurynas, who had graduated from Vilnius Lyceum, pointed out that he was not satisfied with the standard of social and economic studies in Lithuania, thus he decided to choose economic studies abroad. As Estonian and Finland scholars Mare Leino \& Heikki Silvennoinen emphasize, student expectations of the school differ among youth and "not all children adapt well to a school culture that primarily stresses middle class values" (Leino, 2007, p. 76; Silvennoinen, 1992). 
Another reason for moving to a foreign country is curiosity hoping the studies there will be more interesting than in Lithuania. Laurynas maintains that the most decisive factor of choosing the studies abroad was his studies in Vilnius Lyceum and friends, who were already students at a prestigious university in England. There study a substantial number of former Vilnius Lyceum students who would always provide the candidates with information about the studies.

One of the reasons, according to Laurynas, why the university is popular among Lyceum graduates, is historical: the first Lyceum alumni had graduated the same university. However, a more decisive reason is the profiles of the university. One of the two most prestigious universities in England offers future students mainly Bachelor's degree in social and humanitarian sciences, the other one is biased in natural sciences, information technologies, mathematics and engineering. When asked about university studies, Laurynas responded:

I am glad I have studied there although my expectations concerning studies weren't fully met. I hoped for much more. At the time I entered the university I must have viewed life very naively. I have always thought that this university prioritizes intellectual curiosity or science and knowledge as such and there is zero pragmatism concerning these. It was almost true, but I hoped there would more of it there. Indeed, I met there lots of bright people having wide interests, however, science wasn't such a highly valued priority as I imagined. I had a naive idea of how it would look inspite of that, if you ask me whether I'm happy having graduated the university, my response is "yes", surely. I know I have a job which appeals to me.

The fact I've graduated this university to a large extent was a decisive factor my application was considered. I work at a company whose workers mostly are former Bachelor graduates of the two prestigious universities. If you haven't graduated from them, it is very difficult to get a placement in the company I work for. Such practice isn't unusual, this is how London's corporate world system functions striving to recruit certain students. This is the practice of law companies, banks and similar organizations. It means people are segregated, however, the fact you have garduated from a prestigious universitety provides you with lots of opportunities here (RAA LIE, III/26).

Laurynas' interview demonstrates that academic and buisiness carrer of immigrant is closely linked with integration process within the receiving British society. According to Paulius Mackela, "there are two main actors in the integration process, namely immigrants and the receiving society," which voices are not equal (Mackela, 2018, p. 2). Other scholars emphasize, that the integration process of migrants takes place at 3 levels: "personal, collective and institutional" (Penninx, 2010, p. 70). According to Penninx (2010), the first level includes migrants' integration in job, education, and housing process, as well as, their social and cultural adaptation; the second level includes migrants' work together by mobilising their resources and ambitions. The last level includes the public institutions of the receiving society.

According to Penninx, Laurynas' case is an example when the integration process takes place on 3 different levels (personal, collective and institutional). Nevertheless, a lot of researchers emphasize that qualified Eastern Europeans 
occupy low-skilled positions in the UK labour market (Parutis, 2011; Ciupijus, 2011), this case demonstrates that migrants who attend prestigious academic institutions in Britain often become an integral part of the British society.

The second case is connected with Simonas who is curently working in the UK. Simonas, who has graduated from two prestigious universities first obtaining a Bachelor's degree in natural sciences and later choosing Bachelor's studies in medicine and surgery, shared his experience:

From a young age I was dreaming of studies in some other country than Lithuania: we used to travel a lot with my parents. I saw university cities and was impressed by the high standard of studies. I used to take part in various contests at school and represented Lithuania abroad, so I was brave enough to apply to universities in America and England. I was offered partial scholarships by a few American universities, and after I was interviewed at a prestigious university in England, I was invited to study there. As this university seemed to be best of all, I decided to go there...

I chose the program which was mostly oriented towards research and trained students to become future leaders in the field of science, engaged them not only in clinical practice, but provided them with certain ideas how the whole system could be changed. This university is probably one of the most advanced schools of medicine in the whole world. When selecting their future students, they want them to have academic mentality. I enjoyed the program a lot... As I had already studied in England and obtained a Bachelor's degree, I was willing to stay with the same community and work with people who try to change everything... (RAA LIE, III/21).

So, his satisfaction with higher education and integration of emotional component highlights opportunities and challenges that motivates to rethink one's attitudes and to lead to a deep concern for the well-beingo of others. Simonas has expressed the view that his expectations concerning new studies were fully met:

Besides the knowledge I gained at the two universities, where I spent a substantial amount of time, the studies greatly influenced my character and the way of thinking and I am very grateful for that. Surely, you have to work a lot - that's a requirement of the organizational culture. The habits formed prove useful now as well - I try to use my time effectively. Perhaps it's the critical attitude formed that helps you to make certain changes doing the work you care about. We had to write lots of reports and essays - it must have refined our writing and we learnt to present our arguments on a more grounded basis. The studies served not only as a platform of gaining knowledge in a certain field - they helped me acquire certain skills which, I think, is not accessible everywhere (RAA LIE, III/22-23).

In summary, sustainable education requires a sustainable learning and teaching process, as well as creating learning communities and organizations. In such communities critical and creative competencies are valued, also, differential needs and learning styles are recognised and honoured. There, teachers and students participate in the learning process as learners and collaborators (Sterling, 2001; Dzelzkalēja \& Kapenieks, 2018). 
Simonas emhasized a great significance of well-organized timetabale during the workday and breathink space, as well as during working week and weekend:

A term at a university lasts for 8-9 weeks, which means your time has to be well-organized: there's time for sleeping, eating, attending lectures, doing sports, and studying: after the lectures you have to read all the material provided thus getting ready for the following day. Some students attend lectures 6 days per week. Besides, lots of them do sports. Basketball is perhaps the most popular game among Lithuanians. Some of them are members of the university team. Most students have developed a broad world outlook. Some take part in various competitions and games, others spend their weekends singing in musicals in London. They study medicine for the whole week and on weekends they go to London to sing (RAA LIE, III/22).

The supportive, positive, optimistic learning environment is very important for hormonious development of student personality as well as for sustainable education. Although Simonas hasn't been living in Lithuania for 9 years, he is involved in various activities and projects in his motherland. At present he works as a healthcare specialist in Great Britain and conducts clinical reasearch in a hospital. He considers his work satisfying to as much as 80 per cent. In a few years he plans to continue his studies for a doctoral degree either in the USA or in Australia.

As a study of Violetta Parutis (2011) reveals, East European migrants are highly mobile, constantly searching both personal and professional possibilities for progress in the British labour market. The choice to invest in migrants skills in the UK is related to the fact that this gives them certain freedom and flexibility abroad. This is especially to be said about such migrants as Simonas, who would like to reside in such countries as the USA or Australia. As he mentioned in his interview:

Australia is an attractive and interesting country, where one can enjoy lots of freedom and satisfying lifestyle, besides, it provides lots of possibilities for travelling. On the other hand, the salaries there are twice as high as in Great Britain, the work load is more humane and the system is not as loaded as here, also, the period of residency following the studies is shorter (RAA LIE, III/25).

The third case is connected with Irmantas. The career of Irmantas, who graduated from one of the prestigious universities with a Bachelor's degree in psychology and philosophy, is unfolding in the sphere of social work. After he finished his studies, he returned to his native country and worked one year as a team member with the program "Create for Lithuania." The program aims at recruiting young professionals who have studied abroad and gained some valuable practice and are able to make changes in the public sector. Later he studied for Master's degree in social politics in another prestigious university in England and at present works for Lithuanian government.

Irmantas says that he chose England and an advanced university there because of the social environment in Lyceum, where they had a well devel- 
oped system of entering the best universities in England. School graduates did not enter universities in the USA then because they did not know the procedure. It was not long ago (in 2017) that they had access to more information about it through the project "Academic Buddy."

Irmantas maintains that he chose a prestigious university because of two reasons: the program of philosophy and psychology, also, because the university is oriented towards deepening your knowledge which makes it different from another one where they seek to widen it.

I was eager to analyse certain topics more in depth, that's why I have chosen this university. From the present perspective/ having learnt more about studies in London, I am very satisfied with the program I was enrolled in. I've chosen social politics because I am concerned about Lithuania (RAA LIE, III/41- 42).

Irmantas also spoke about shifts in perceiving his own identity:

I came to a foreign country being a considerably strict Lithuanian and an ardent patriot. I was very much concerned about Lithuanian culture, anything of Lithuanian origin seemed to be bettter. When travelling round England, I couldn't help but think critically about everything that was of English origin. In my mind Lithuanian quality outweighed English. Within two years I developed more moderate views. It was a natural process because I got to know foreigners better and understood that they are people like us and foreign countries are somewhat similar to Lithuania. We have more or less the same problems and different opinions... I started perceiving my identity in a more moderate way and understood that other countries can also boast of good things and Lithuania can learn a lot from them.

Personal identity has to do with meaningful activities I want to indulge in, for example, when choosing to create people's welfare I can decide whether to do it in Lithuania or abroad. So far I was sure I wanted to work in Lithuania and no other country. I am not really tempted to pursue a career in international organizations - a lot of people from my environment decide on working for them. I am also considering scientific career - a small change made turns out to be global because any discovery is of global significance.

Why have I chosen to do public politics in Lithuania? I wanted to concentrate my activities in Lithuania so that the country could profit from it as much as possible. Things started changing this year. At present I am nurturing the idea of some work on a more global scale that would be beneficial not only to Lithuanian people, but to the whole of Europe, even the world - I consider the idea of getting involved in some scientific activity in order to make certain changes, discover something new which would change the view on the politicians in the whole world. On conceptual grounds it is, by all means, very ambitious, however, from a theoretical perspective it might be a different way of acting (RAA LIE, III/44).

The case of Irmantas demonstrates that academic and business career of immigrants is also closely linked with identity changes. It's possible to remember Märtsin's idea that the conceptualization of identity moves "from understanding identity as a fixed and relatively stable entity" to a "fluid, multiple, fragmented, dialogical, constantly re-constructed" process (Märtsin, 2010b, p. 66). 
The fourth case is the experience of Vaida, who comes from Northern Lithuania, the city of Panevėžys. Vaida graduated a prestigious gymnasium of Juozas Balčikonis and came to England at quite an early age. After she turned 18, during summertime and Christmas season she used to work in a restaurant in England in order to earn money for her studies. In 2004 she graduated from Vilnius University with the Bachelor's of Science degree in Biochemistry and left for England. She wanted to learn the value of the Vilnius University diploma. A month later she was hired as a research specialist in a huge DutchBritish transnational consumer goods company "Unilever." There she learnt about corporative work in a company which has high standards, committed leaders and cares about its workers. Encouraged by one of them two years later she enrolled in a doctoral programme in a prestigious university in England. The choice of the university was made having heard the managers talk about it when engaging new workers. From a mass of applicants they selected five graduates of two prestigious universities. A few years later Vaida graduated one of them with the Biochemistry Master's degree. She recalls her university experience:

I didn't attend lectures at the university because laboratory was my workplace. The circle of people I contacted was perhaps narrower as I had no study friends. Lab environment was the one I lived in. But on the whole the university rallied people of high calibre. Such surrounding environment enables you a lot because you understand how much one can achieve, what research could be done and publications made. The impact you can have in this or that field of science solely because you deal with this or that matter or do research in a certain field. The feeling is beyond comparison. As my curriculum didn't include lectures I could attend other ones - those delivered by, let's say, some professor, Nobel prize laureate. One was allowed to attend such lectures. It was very interesting for me. I used to attend different lectures, dealing not only with the field of my interest. I even attended lectures on business in Saïd Business School - I liked them immensely. They were on science of biology and business. One finds oneself in a special medium there: people come with very concrete hobbies, wishes and aims. The studies proved to be useful, although I didn't finish the way I intended. In spite of that I am greatly satisfied with my university studies (RAA LIE, III/59).

Vaida did not complete her doctoral studies because of unfavorable circumstances, however, obtained a Master's degree at the university. The example presented in the paper focuses on her academic life and private business experience:

I didn't continue my doctoral studies because I understood I didn't want to be a scientist - I didn't see myself in that role. Especially when I worked in a dark lab by the microscope, all alone from morning till night. When counting the cells and experimenting I thought I wasn't doing the right thing: I am a strong extrovert, I like socialising. I was asking myself why I'd chosen such a path. I saw the reaction of my tutor when he was refused finansing for his lab. I saw the stress he experienced. I thought: Oh, God, he is only 45 , and every 4 or 5 years he has to apply for new grants and he didn't get them. It created a confusion in the lab. I couldn't see myself in all that matter, in that environment. And I started thinking about something 
different. When I finished (completed my Master's studies), I decided to get back to work with real property (...) I became involved in interior design - something I liked immensely. You know, my sister is an architect - architecture is somehow distilled in our family, it flows in the air (...) I threw myself to the construction site, one might say. My work was as follows: I looked for a facility - a house or an apartment - that I would like to buy. I checked its potential. Then I would put it in order: I hired people, a team I would work with. After renovating the facility I would either let it or sell it. The money earned was reinvested again. You know, I found myself in a completely different "emploi." I liked the work immensely. All the skills that I acquired in a laboratory turned out to be very useful because I managed to plan my work well. Looking at my present life it seems to me this is the style of my work (RAA LIE, III/57-58).

Vaida did not intend to become a scientist - she started the business of real esatate and founded her own enterprise in the city she studied. For a year she worked with the project "Create for Lithuania" in her native country and later together with her Italian husband settled in Germany where she successfully continues her private business in the UK and conducts research in Germany.

The case of Vaida helps to understand Märtsin who proposed an alternative conceptualization of identity, which postulates identity as "an idiosyncratic semiotic construction (...) triggered by a rupturing life-experience" (Märtsin, $2010 \mathrm{~b}, \mathrm{p} .78)$. It reveals another perspective and makes the person aware of the possibility to be different.

The analysis of the empirical research data reveales different experiences of the academic youth. It divulges that students give more value to high level of education, creativity and individualism emphasizing possibilities to apply knowledge to the career in international business or academic field. It should be noted, that sustainable education plays an important role in sustainable development of personality.

\section{CONCLUSION}

Concluding this article dealing with the situation of Lithuanian students at prestigious universities in the UK, we can point out that the determining factor of their choice was the high quality of the studies and work perspectives after graduation, also, high rating of three top universities and the recommendations of senior fellow students, progressive learning and living environment.

On the whole, the expectations of the students were fully met - only a small percentage of respondents mentioned they hoped for more. Almost all the graduates pointed out they had gained thorough knowledge, acquired academic skills and learnt to organize their time in order to be able to bear heavy work loads. Besides sustainable education, satisfaction of studies process, also, well-being they had the possibility to become part of the international social web - it is extremely important when looking for a job and pursuing one's career in the field of science or business. 
The results of the survey indicate that students from prestigious universities give more value to individualism emphasising achievement, critical thinking, high level of sustainable education and possibilities to apply knowledge in real-world setings, also, to the career in international business or academic field, which is guaranteed by most reputable universities. It should be admitted, that academic youth, who are studying abroad at prestigious universities, have a lot of opportunities to become future leaders in the field of science or business, to create new international networks, and to work together with people who try to change the world. In such evironment students are encouraged to be responsible actors who resolve challenges, respect cultural diversity and create a more sustainable world (UNESCO (ESD), 2017).

\section{ACKNOWLEDGEMENT}

The research has received funding from the Council for the Protection of Ethnic Culture under the project "Cultural and Religious Identity of Lithuanians in England." Grant agreement number (No. SA-1) in 2017.

I would like to thank all the individuals that were involved and helped with research as well as those who shared their stories in qualitative interviews and invited their friends to participate.

\section{REFERENCES}

[1] Aidis, R., \& Krupickaitè, D. (2007). Jaunimo emigracijos tyrimas: Lietuvos universitetiniu aukštuj]ų mokyklų studentų nuostatos emigruoti [Youth emigration: migration tendencies amongst university students in Lithuania]. Oikos: lietuviu migracijos ir diasporos studijos, 3, 36-50.

[2] Aidis, R., \& Krupickaitė, D. (2009). Kaip neiššvaistyti protų: Lietuvos studentu nuostatos emigruoti [Mitigating brain drain: migration tendencies of students in Lithuania]. Vilnius: Vilniaus universiteto leidykla.

[3] Antinienè, D., \& Lekavičienė, R. (2018). Lietuvos studentų emigracinès nuostatos: struktūra ir kaita 2003-2017 m. [Lithuanian students' attitudes towards emigration: structure and shift during 2003-2017. Pedagogika, 132 (4), 63-80.

[4] Bell, D. V. J. (2016). Twenty-first Century Education: Transformative Education for Sustainability and Responsible Citizenship. Journal of Teacher Education for Sustainability, 18(1), 48-56. doi: 10.1515/jtes-2016-0004.

[5] Brooks, R., \& Watters, J. (2011). Student Mobilities, Migration and the Internationalization of Higher Education. New York: Palgrave Macmillan.

[6] Brown, P., \& Tannock, S. (2009). Education, meritocracy and the global war for talent. Journal of Educational Policy, 24(4), 377-392. doi: 10.1080/02680930802669938.

[7] Ciupijus, Z. (2011). Mobile central eastern Europeans in Britain: successful European Union citizens and disadvantaged labour migrants? Work, Employment $\mathcal{E}$ Society, 25(3), 540 -550. doi: 10.1177/0950017011407962.

[8] Didžgalvytė, M., \& Pukelienè, V. (2010). Protụ nutekèjimas: užsienyje magistrantūros ar doktorantūros studijas baigusiụjų reemigracijos analizè ir vertinimas [Remigration analysis and evaluation of Lithuanian students studying master or doctorate abroad]. Taikomoji ekonomika: sisteminiai tyrimai, 4(1), 123-138.

[9] Dolby, N., \& Rizvi, F. (Eds.). (2008). Youth Moves: Identities and Education in Global Perspective. New York: Routledge. 
[10] Dzelzkalēja, L., \& Kapenieks, J. (2018). Contradictions in Higher Education. Journal of Teacher Education for Sustainability, 20(1), 124-144.

[11] Grandcolas, U., Rettie, R., \& Marusenko, K. (2003). Web survey bias: Sample or mode effect? Journal of Marketing Management, 19(5-6), 541-561.

[12] Hazans, M. (2015). Smadzeņu aizplūde no Latvijas 21 gadsimtā [Brain drain from Latvia in the 21st century]. In: I. Mierina (Ed.), Latvijas emigrantu kopienas: Ceribu diaspora [The emigrant communities of Latvia: diasporas of hope] (pp. 88-92). Riga: Latvijas Universitātes aǵentūra Latvijas Univeristātes Filozofijas un socioloǵijas institūts.

[13] Hart Research Associates. (2015). Falling Short? College Learning and Career Success. Selected Findings from Online Surveys of Employers and College Students Conducted on Behalf of the Association of American Colleges \& Universities. Retrieved January 20, 2020, from

[14] https://www.aacu.org/sites/default/files/files/LEAP/2015employerstudentsurvey.pdf

[15] Kaša, R. (2015). Latvijas studentu augstākās izglītības studiju finansēšana ārzemēs [Financing of higher education studies of Latvian students abroad]. In: I. Mierina (Ed.), Latvijas emigrantu kopienas: Ceribu diaspora [The emigrant communities of Latvia: diasporas of hope] (pp. 93-107). Riga: Latvijas Universitātes aǵentūra Latvijas Univeristātes Filozofijas un socioloǵijas institūts.

[16] Kaša, R. (2019). The nexus between the higher education funding and return migration examined. In: R., Kaša, \& I., Mierina (Eds.), The Emigrant Communities of Latvia. National Identity, Transnational Belonging, and Diaspora Politics (pp. 283-298). Cham: Springer Open.

[17] Kvedaraitè, N., Bakšys, D., Repečkienè, A., \& Glinskienė, R. (2015). Research of experience of emigration for employment and education Purposes of Students. Inžinerine ekonomika/ Engineering Economics, 26(1), 196-203.

[18] Kvedaraitè, N., Repečkienè, A., Glinskienė, R., \& Bakšys, D. (2011). Akademinio jaunimo migracijos patirties tyrimas [Study of academic youth's experience of migration]. Profesiness studijos: teorija ir praktika, 8, 220-226.

[19] Leino, M. (2007). Sustainable Education and Socialization through Mistakes. Journal of Teacher Education for Sustainability, 7, 67-78. doi: 10.2478/v10099-009-0006-5

[20] Lekunze, L., M., G., \& Strom, B., I., (2017). Bullying and Victimisation Dynamics in High School: An Exploratory Case Study. Journal of Teacher Education for Sustainability, 19(1), 147163. doi: 10.1515/jtes-2017-0010.

[21] Mackela, P. (2018). Eastern Europeans in Britain: Successfully Integrated Citizens or Alienated Migrants? A Case Study of the Lithuanian Migrant Community in London. Undergraduate Journal of Politics and International Relations, 1(3), 1-12. doi: 10.22599/ujpir.46

[22] Matthews, J., \& Sidhu, R. (2005). Desperately seeking the global subject: international education, citizenship and cosmopolitanism. Globalisation, Societies and Education, 3(1), 49-66. doi: 10.1080/14767720500046179.

[23] Merkys, G., Baršauskienė, V., \& Antinienė, D. (2006) Lietuvos studentų emigracinės nuostatos ir jas lemiantys veiksniai [Emigration attitudes of Lithuanian students and the factors influencing them]. Sportas, 3(62), 36-42.

[24] Märtsin, M. (2010a). Commentary: Making sense of identity dialogues. Culture \& Psychology, 16(1), 109-115. doi: 10.1177/1354067X09353210.

[25] Märtsin, M. (2010b). Rupturing Otherness: Becoming Estonian in the Context of Contemporary Britain. Integrative Psychological and Behavioral Science, 44, 65-81.

[26] Mierina, I. (2019). An Integrated Approach to Surveying Emigrants Worldwide. In: R. Kaša, \& I. Mierina (Eds.), The Emigrant Communities of Latvia. National Identity, Transnational Belonging and Diaspora Politics (pp. 13-33). Cham: Springer Open.

[27] Mierina, I. (Ed.). (2015). Latvijas emigrantu kopienas: ceribu diaspora [Latvian emigrant communities: The diaspora of hope]. Rīga: LU Filozofijas un Socioloǵijas institūts.

[28] Mierina, I., \& Koroḷeva, I. (2015a). Metodoloǵiskie risinājumi emigrantu viedokḷu izzināšanai pētijumā [Methological approaches to studying emigrant perspectivesin the study Latvian Emigrant Communities]. In: I. Mierina (Ed.), Latvijas emigrantukopienas: ceribu diaspora [Latvian emigrant communities: The diaspora of hope] (pp. 26-41). Rīga: LU Filozofijas un Socioloǵijas institūts.

[29] Mierina, I., \& Koroḷeva, I. (2015b). Negotiating Identities and Friendships while Living Abroad: Experiences of Latvian Migrants. European Scientific Journal, August 2015, 352-368. 
[30] Parutis, V. (2011). "Economic Migrants" or "Middling Transnationals"? East European Migrants' Experiences of Work in the UK. International Migration, 52(1), 36 - 55.

[31] Parutis, V. (2013). Returning "Home": East European Migrants' Discourses of Return. International Migration, 52(5), 159-177.

[32] Penninx, R. (2010). Migration and Its Challenges for Trade Unions in Europe. In: G. Biff (Ed.), Migration and Integration: Dialog zwischen Politik, Wissenschaft and Praxis (pp. 69-81). Bad Voslau: Omnimum.

[33] RAA LIE (Personal archive of manuscripts of Rasa Račiūnaitè-Paužuolienè, Lithuanians' Identity in England). (2017). File. I-IV. Recorded by R. Račiūnaitė-Paužuolienè in England and Lithuania in 2017.

[34] Račiūnaitė, R. (2002). Moteris tradicinèje lietuviu kultūroje. Gyvenimo ciklo papročiai (XIX a. pab.XX a. vid.) [Woman in Traditional Lithuanian Culture: The Customs of Life Cycle (at the end of 19th - middle of the 20th c.c.]. Kaunas: Vytauto Didžiojo universiteto leidykla.

[35] Račiūnaitè-Paužuolienė, R. (2017). Anglijos lietuviụ kultūrinè ir religinè tapatybė [Cultural and Religious Identity of Lithuanians in England]. Kaunas, 1-28. Retrieved October 10, 2020, from http://www.ekgt.lt/media/dokumentai/veikla/Tyrimai/2017tyrimai/Pauzuoliene_ tyrimas.pdf

[36] Račiūnaitė-Paužuolienė, R. (2019). „Tapatybè tarsi sala“: Anglijos akademinio jaunimo atvejis ["Identity as an Island": a Case Study of Lithuanian Academic Youth in England], LOGOS, 100, 198-210. doi:10.24101/logos.2019.64

[37] Rakauskiene, O., G., \& Ranceva, O. (2012). Strengths of Emigration from Lithuania: Demographic, Social and Economic Consequences. Intellectual Economics. Vol. 6, 2 (14), 245-257.

[38] Ramanauskaitė, E., Vaišnys, J., R., Kairaitytè, A., \& Buivydas, A. (2013). Lietuvos akademinio jaunimo migracija: studiju aplinkos ittaka sprendimams. Mokslo studija [Lithuanian student migration: the influence of study environment on decisions]. Kaunas: Vytauto Didžiojo universitetas.

[39] Ramanauskaitė-Kiškina, E., Vaišnys J., R., \& Kairaitytė-Užupè, A. (2015). Visuomenés grupiu tyrimai. Metine apžvalga. 2013-2014. Lietuvos akademinio jaunimo migracija: studiju aplinkos ịtaka sprendimams [Studies of society groups. Annual Review. 2013-2014. Lithuanian student migration: the influence of study environment on decisions]. Kaunas: Versus Aureus.

[40] RFCDC.(2018). Vol. 1. Context, concepts and model. Strasbourg: Council of Europe Publishing. Retrieved March 20, 2020, from https://rm.coe.int/ prems-008318-gbr-2508-reference-framework-of-competences-vol-1-8573-co/16807bc66c

[41] Repečkienè, A., Kvedaraitė, N., \& Žvirelienė, R. (2009). External and Internal Migration in the Context of Globalization: Higher School Graduates' Attitude. Ekonomika ir vadyba, 14, 603-610.

[42] Sipavičienè, A., Jeršovas, M., \& Radzevičius, I. (2013). Studentu migracija: teorinis diskursas ir situacija Lietuvoje [Student migration: theoretical discource and situation in Lithuania]. Lietuvos socialine raida: Migracija ir etniškumas [Social Development of Lithuania: Migration and Ethnicity], 2, 52-70.

[43] Silvennoinen, H. (1992). Rejection and Schooling [Huono-osaisuus ja koulutus]. Kasvatus [Education], 3, 256-267.

[44] Skačkauskaitė, A. (2007). Tarptautinès lietuvių migracija: studentų nuostatos, požiūris ir emigraciniu galimybiụ ịvertinimas [International Lithuanian migration: how students look at it]. Oikos: lietuviu migracijos ir diasporos studijos, 3, 51-60.

[45] Stasulane, A. (2017). Factors Determining Children and Young People's Well-being at School. Journal of Teacher Education for Sustainability, 19(2), 165-179. doi: 10.1515/jtes-2017-0021.

[46] Sterling, S. (2001). Sustainable Education. Re-visioning Learning and Change. Devon: Green Books.

[47] The Times Higher Education World University Rankings. (2018). Best universities in Europe 2018. Retrieved January 22, 2018, from https://www.timeshighereducation.com/student/ best-universities/best-universities-europe

[48] QS World University Rankings 2016-2017. (2016-2017). Top 10. Retrieved December 21, 2017, from https://www.topuniversities.com/university-rankings-articles/ world-university-rankings/qs-world-university-rankings-201617-out-now

[49] UNESCO (ESD). (2017). Education for sustainable Development. Retrieved December 20, 2019, from https://en.unesco.org/themes/education-sustainable-development 